\title{
Editorial
}

\section{Polar Research}

During recent years polar research has been a field of increasing international activity. The reason for this development is not simply an economic one, e.g. regarding mineral, biological or fresh water (icebergs) resources in these zones, but more a scientific necessity. The polar regions are not only composed of very special geosystems, which need to be studied, but they are also areas of special importance for meteorology and climatology, for the understanding of the geologic and geomorphic history of our planet, for glaciological records, oceanographic circulation, biological developments etc. Therefore, polar research is a must for all nations with a well developed scientific infrastructure.

The international activities in polar areas can be demonstrated by the combined efforts in Antarctica under the Antarctic Treaty organized by SCAR (Scientific Committee on Antarctic Research) as well as by the 4th International Permafrost Conference in Fairbanks/ Alaska (July 1983) organized by Troy Péwé. Looking at these activities, it is impossible to display a complete overview on Polar Research in one issue of GeoJournal. Therefore, only some highlights can be discussed. This especially includes the recent expeditions and activities in Antarctica by the newly founded Alfred Wegener Institute for Polar Research (Bremerhaven/Federal Republic of Germany) reported by its director. Special topics (periglacial phenomena or climatic indicators or studies on the water balance in permafrost regions) are examples for recent research interests. Whereas Antarctica is defined (by the Antarctic Treaty) as the area south of latitude $60^{\circ} \mathrm{S}$ the Arctic zone is supposed to be situated north of the northern forest line. There do exist boundary problems, because the transition is not abrupt, but gradual. Therefore, in the northern hemisphere subarctic research (e.g. at Kevo Research Station, Finland) are an essential part of polar research programs. Last not least, it is important to remember the men who studied polar areas with unlimited effort and under conditions much harder than today. Alfred Wegener is one of those, who gave their life for the advancement of our knowledge of these areas. When working today in Antarctica or in the Arctic we are obliged to them.

Dietrich Barsch, Heidelberg 